\title{
The issue of a competitive national innovative system formation in Uzbekistan
}

\author{
Konstantin Kurpayanidi ${ }^{1, *}$, Alisher Abdullaev ${ }^{1}$, Mahammadjanov Ashurov ${ }^{1}$, Mukhayyo \\ Tukhtasinova $^{1}$, Yulduzkhon Shakirova ${ }^{1}$ \\ ${ }^{1}$ Ferghana Polytechnic Institute, 150107, Fergana, Uzbekistan
}

\begin{abstract}
The target article analyzed some issues of the formation of a modern competitive national innovative system in the Republic of Uzbekistan. The effective and methodical tools of the research are based on the application, in the framework of a systematic approach of general scientific research methods: logical and situational analysis, expert assessments, questionnaires, observation, interviewing, groupings, and comparison. The article specified and supplemented the theoretical and methodological provisions of the theory of the formation of the innovative national model. The authors proved that the existing mechanism for managing the scientific-research and innovative activity in the country does not meet the requirements of competitiveness based on the systematic analysis of the NIS elements of Uzbekistan and innovative development and its relationships. It is crucial to formulate an entirely universal and effective national innovative system that is adequate to the growing demand for innovations necessary for areas of the national economy, offering support for the innovative activity at each phases of the innovative cycle. Anticipated increase in demand and cost escalation of innovations, incorporating extra actions to encourage foreign direct investments, will stimulate the processes of structural change of the economy in the domain of high-technological sectors increase.
\end{abstract}

\section{Introduction}

World experience convincingly proves that innovative technologies have become the most important effective means and conditions for the development of a modern production and economic potential of the country. They combine advanced achievements of science, possibilities of implementing the latest engineering and technical solutions and modernizing production, mastering production of new types of products, their mass distribution and market distribution [1].

\footnotetext{
*Corresponding author: w7777@mail.ru
} 
In modern economic theory, an innovative way of development of industrial enterprises, which are the primary source of generating added value, is recognized as central and often only possible for long-term and steady economic recovery in industrial production.

Formation and realization of a high-performance investment strategy in the economy is one of the pillars of the long-term economic policy, the determining condition for the stable position of the company, both in external and domestic markets.

Achievement of the innovative and technological development is critically important for Uzbekistan, since only through this way it is possible to create a modern technological base, produce competitive products, rational use of natural resources, increase the efficiency of agriculture, and strengthen the international competitiveness.

\section{Literature review}

The development of the research topic. Various studies have examined the issues of the innovative development by both national and foreign researchers. Research of the following foreign authors as Peter Drucker [1], Mansfield, E., \& Lee, JY [2], Robert Åke Nilsson [3], Michael Eugene Porter [4], B. Szántó [5], BC Twiss [6], Joseph Alois Schumpeter [7], Sidney Graham Winter [8], Christopher Freeman [9], Bengt- Åke Lundvall [10], Jang, E [11]., and others have greatly contributed to expand the concept.

Research works of many scientists and economists of the CIS countries are devoted to the study of the innovative issues: A. I. Anchishkin [12], V. M. Anshin [13], V. N. Arkhangelsky [14], A. A. Dagaev [15], N. B. Ermasova [16], L. E. Mindeli [17], K. F. Puzyni [18], N.Z. Solodilov [19], A.I. Tatarkin [20], R.A. Fathutdinov [21] and others.

S. S. Gulyamov [22], M. A. Ikramov [23], A.M. Kadyrov [24], M.A. Makhkamov [25], M.P. Narzakulov [26], A.F. Rasulev [27, 29], D.V. Trostyansky [28, 29] and others are among prominent scientists of Uzbekistan who investigated the problem under discussion and its separate aspects at different times. The issues of assessing the innovative activity and innovative management have been discussed in the research works of I. Ansoff [29], M. Meskon [30], F. Yansen [31], L. S. Valinurova [32], G. Ya. Goldstein [33], M. P. Golik [34], S. V.Ildemenov [35], and others.

At the same time, inadequate attention is paid to the formation of issues to intensify the innovative activities of the national industrial enterprises of the Republic of Uzbekistan. Moreover, constant change of the external operating conditions and internal factors of industrial enterprise's development determines the need for improving methodological approaches to identify the priorities for the development of the innovative activity. It also requires specification and justification of instruments of the state support for the innovative action.

The target scientific research topic has been chosen due to the actuality of these problems, lack of knowledge, and degree of development.

The practical and exact tools of the target research are based on application, within the framework of a systematic approach of the general scientific research methods: logical and situational analysis, expert assessments, questionnaires, observation, interviewing, groupings, and comparisons.

Let us consider the goal of our study - some issues of the new innovative model formation in the Republic of Uzbekistan.

Based on the purpose of the study, the object of this study will be the National Innovative System [1] of Uzbekistan, its state, potential, and contribution to the economic development and competitiveness.

The NIS, according to Christopher Freeman (1987), is defined as "a network of institutions in public and private sectors whose activities and relationships are to initiate, import, modify and diffuse new technologies [36]". 
At the same time, Danish scientist Bengt-Ake Lundvall (1992, 2012) noted, "Elements and relationships that interact in production, dissemination, and application of new, cost-effective knowledge that is either related to the state boundaries [37].

There are many schematic representations of a typical NIS. In the diagram below, factors conducive to the development of innovations are grouped into three logical groups, highlighting the role of financial and organizational tools to stimulate and commercialize innovations.

\section{Methodology}

The theoretical and methodological basis of the study were the results of studies of domestic and foreign scholars on issues of strategic and innovation management, innovation management and investments, the economy of the industrial enterprise, legal acts of legislative and executive authorities. Methods of comparative technical and economic analysis, processes of expert estimates, the methods of correlation and regression analysis were used and concretized in the models of innovation management.

The adopted research methodology using a specific toolkit will ensure adequate object, subject and methods of research, and to obtain reliable results.

As an information base study used official materials of the State Committee on Statistics of the Republic of Uzbekistan, the Ministry of Economics and Industry, legal documents, proceedings of conferences and symposia, the official statements of the industrial enterprises of the Republic of Uzbekistan, published in periodicals and online publications.

\section{Discussion and results}

The first group of NIS elements is essential, but unsatisfactory terms for the growth of innovations. Specifically, these include the human potential, the improvement of the information and communication technology segment, the effectiveness of the system that protects the intellectual property rights as well as a favorable business environment for running business activities, involving the quality of public administration.

The second group includes tools to support and encourage innovations. They imply the availability of financial instruments to support changes (such as grants, concessional and guaranteed lending), and organizational (scientific and technical business incubators, technology parks, technology transfer agencies, business matching events (fairs), etc.

Nowadays, [1] several organizations performing the research and development activities constitute 668 units, including 233 groups of private sector enterprises in the country. All these enterprises produced scientific products in the amount of 680.038 billion soums.

The innovative system is a combination of organizational, legislative, structural, and functional components that ensure the development of innovations. The current national innovative system (NIS) of Uzbekistan, having undergone some significant changes, is still at the stage of its formation. At the same time, its elements, in particular, the relationship between science and industry, have to be restored with adaptation to new market relations, and some parts of it, for example, the commercialization of developments, must be created from scratch. The difficulty in forming a genuinely useful innovative system is the complexity of problems that need to be solved. The development strategy of the innovative national systems of various states is built based on the macroeconomic policy, scientific and technological potential, political, legal, social, and cultural characteristics, and, accordingly, cannot be repeated in other countries. Yet, similarities in the essential elements of the NIS and the range of issues require a solution. The innovative policy in Uzbekistan is determined by the President and the Cabinet of Ministers. Republican governmental authorities implement it, local government authorities within and following their virtue. 


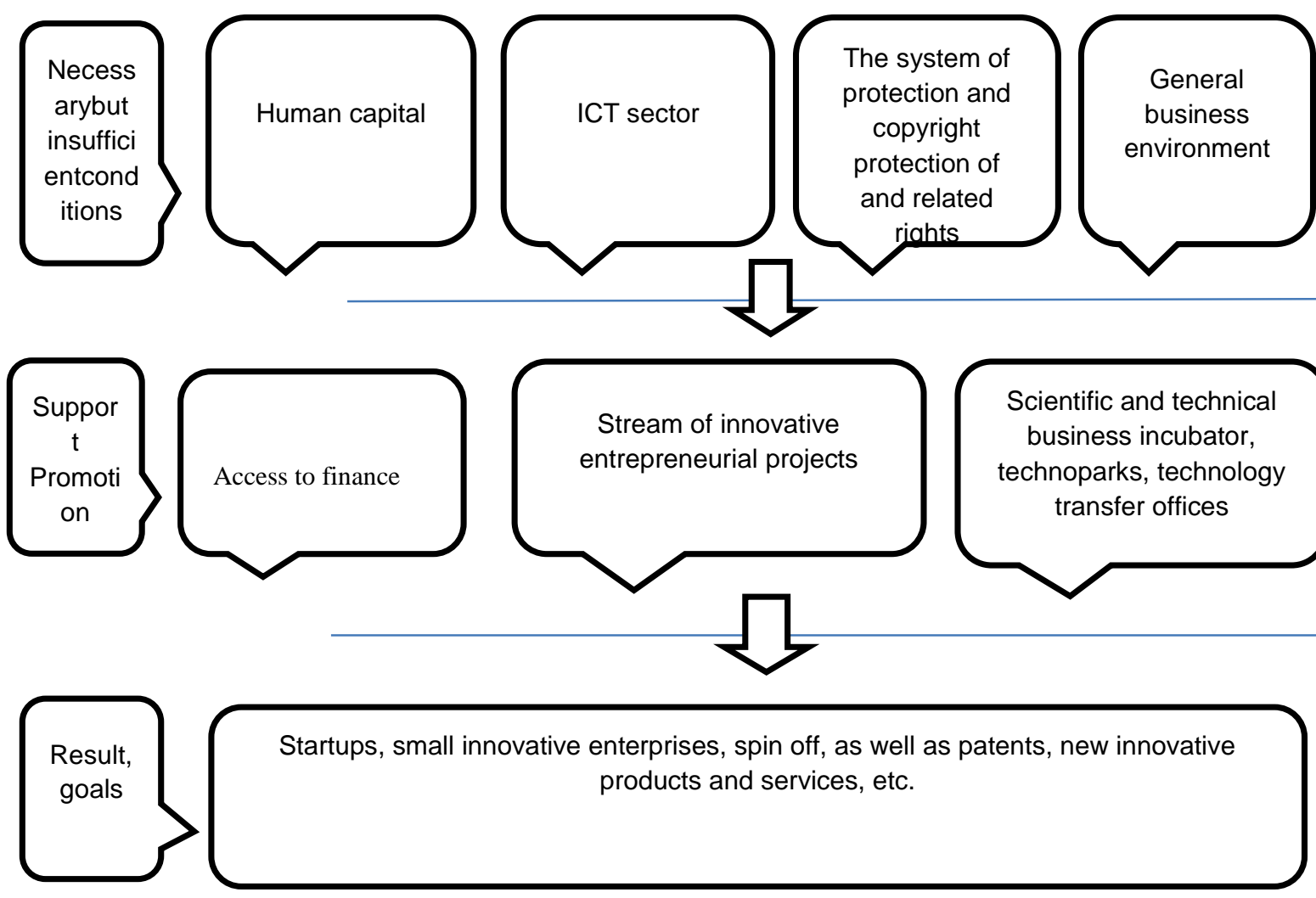

Fig. 1. Modified NIS chart based on the World Bank's proposed Public Financial Support for Commercial Innovation.

The basis of the current system of the state regulation of science and technology was laid by the Decree of the President of the Republic of Uzbekistan PP-2789 dated 02.17.2017 "On measures on further improvement of activities of the Academy of Sciences, the organization, management and financing of the research activities."

To improve further the activities of the research institutions, strengthen the material, technical and experimental laboratory base, create conditions for the development of the innovative activity 9 research institutes within the Academy of Sciences were restored. A number of scientific institutions were reorganized, 3 branches of the Academy of Sciences were structured in scientific areas, including the Navoi branch. The activities of the Public Council on the Recent History of Uzbekistan, the State Commission on Science and Technology, the Agency on Science and Technology, and the Foundation for Support and Development of Scientific and Technical Activities were systematized.

The next resolution "On measures to strengthen further the infrastructure of the research institutions and innovative activities development" has been recently signed by the President of the Republic of Uzbekistan which restates further strengthening of the foundation of comprehensive systemic changes in the country on the development of scientific and technological activities [38].

The resolution approved a program of comprehensive measures to strengthen the infrastructure of the research institutions and the development of innovative activities, 
including over 40 events in 6 priority areas in the field of science and innovations for $2017-$ 2021 years.

It is estimated to allocate more than 116 billion soums to the Academy of Sciences and other ministries and departments for the reconstruction and overhaul of buildings and structures of the research institutions in 2018-2021. Furthermore, over 32.2 million US dollars is spent on equipping modern scientific and laboratory equipment, providing necessary materials and components.

The overall coordination of the scientific and technological spheres is carried out by the Ministry of Innovative Development of the Republic of Uzbekistan [39]. These tasks include:

- implementation of unified state policy in the field of innovative, scientific and technical development of the Republic of Uzbekistan, aimed at the comprehensive development of public and state life, increasing the intellectual and technological potential of the country;

- conducting an assessment of innovative activity based on indicators of its effectiveness determines the main directions of development of the relevant industries and areas that require a primary implementation of advanced technologies;

- Coordination of activities of the governmental bodies, research institutes, information, and analytical institutions and other organizations on the implementation of innovative ideas, development, and technologies;

- be a single customer of the governmental scientific and technical programs and projects implemented by research, educational, and other institutions.

Thus, the innovative system in the Republic of Uzbekistan represents the completed form shown in figure 2.

Our systematic analysis of the elements of Uzbekistan NIS and their interrelations revealed several problems, the solution of which is essential for innovative development:

Firstly, almost every aspect of the NIS suffers from the presence of severe interrelated issues, as a result, the system is not holistic, and so far cannot provide innovative development. For example, the commercialization of innovative solutions is complicated by the uncertainty of the distribution mechanism of intellectual property rights created by the governmental institutions or at the expense of the state funds.

Secondly, in practice, the functioning of individual elements of the NIS is aimed at solving different specific problems that are not subject to the general goal of innovative development, and in some cases, even create additional difficulties. In particular, the system of mandatory product certification and registration of export contracts increases the transaction costs of exporting the outcomes of the innovative activities, thereby limiting the output of the domestic products abroad.

Third, there is no targeted and innovative policy, which is developed as a medium- and long-term program document, which sets priorities, sets objectives, and includes steps to achieve these guidelines. Existing programs for localization and development of local businesses [1] facilitate modernization, increase the technical level of production, and require the establishment of competitive export-oriented products and replacement of imported products. However, these programs do not look for appropriate steps to stimulate the introduction of innovations in the development of local scientific potential, training and training of staff, the creation of supporting structures and production. Fourth, the NIS elements do not communicate well enough with each other, thereby reducing the flow of information, promoting product innovations and inadequate staff training to meet the needs of employers. 
Fifth, lack of budget funds allocated to $R \& D$, inefficiencies in scientific and innovative activities and opacity of public funds, lack of incentive mechanisms to attract funds from offbudget and private sources. Insufficient development of debt funding sources. Existing mechanisms for managing research and innovative activities that the Ministry of Innovative Development has been conducting since 2017 have not yet addressed the challenges of innovative development:

- Poor stability in the establishment of incentives and mechanisms for the innovative activity

- Organization of the innovative improvement is inadequately implemented.

Presently, direction of the investigation, the economic and social sector's activities are limited to evaluate compliance of the research with widely stated priority areas:

- Priority areas are formed including any research in this area, irrespective of their concrete realistic significance and do not contribute to the expansion of specific strategies and programs;

- The present regulatory environment has the following drawbacks:

- Absence of a central law in the field of innovations and fixed fundamental concepts in civil law;

- existence of legal gaps in regulating the rights on the results of intellectual activity built by budgetary funds or by state organizations, and association of rights on the results of the scientific and technical operations in the economic revenue; lack of standards that offer organizations with opportunity of securing and disposing of exclusive rights on the results of intellectual activity formed by them, incorporating those built through budget financing, as well as income from use of these results;

- Deficiency of a proper method for the management of intellectual property rights [40] .

[1] Specifically, programs for the development of the pharmaceutical, chemical, oil and fat, ginning, railway industries, and the production of construction materials.

Scientific organizations, due to gaps exist in determining the rights on the results of intellectual activity, do not have a specific and robust strategy or approved procedure for making a profit from innovative businesses.

In general, the next central problems of the current innovative environment can be distinguished, the pendency of which negatively influences the growth of the innovative national potential:

- shortage of a methodical, clearly structured lawmaking structure for the implementation of all stages of the innovative process, as well as measures for its state support, including direct (budget financing) and indirect (tax preferences, state guarantees, etc.) mechanisms, as well as the legal framework governing the conditions for creating enterprises and the norms of relations between the subjects of innovative infrastructure;

- insufficient solvent need in the national market for high-level technologies and innovations, low demand by the real sector of the economy for encouraging results of scientific and technical activities for their commercial purpose, absence of an organized market for innovative products;

- unelaborated novel monetary tools of some perspectives of innovation infrastructure support, innovative entrepreneurship and independent, innovative projects, particularly risk financing funds (venture funds), appropriate financial tools to support firms at the stage of their accelerated growth, approved appraisers of firms and intellectual property, protection of innovative investments, leasing of high-tech equipment and devices, stock market for hightech companies, trading houses, etc. 


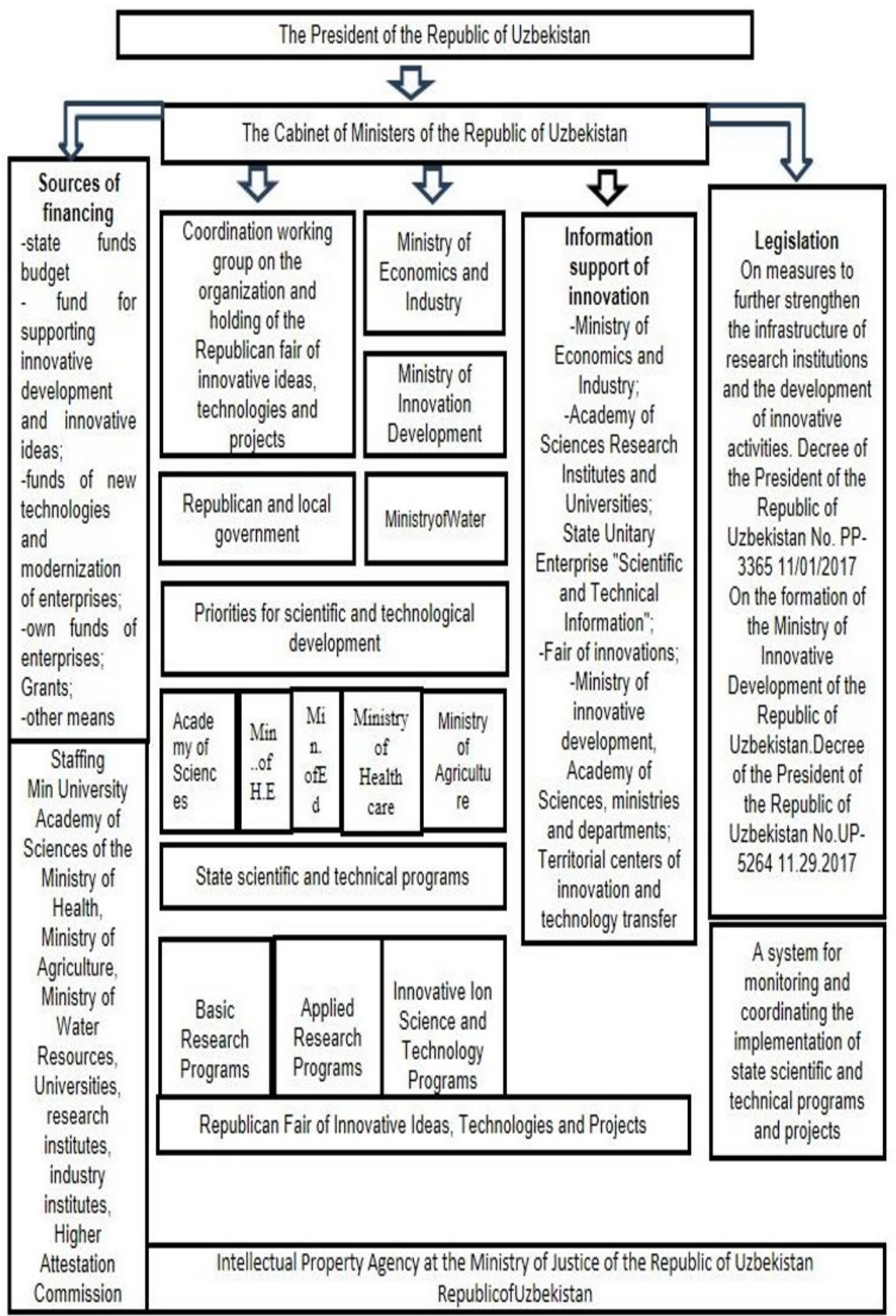

Fig. 2. Structural model of the National Innovation System of Uzbekistan 
- shortage of adequate mechanisms for the implementation of state-defined preference fields for the advancement of science and technology, the multiplicity of scientific organizations that require to be supported by the government. The outcome is the dispersal of budgetary funds and underfunding of investigation in promising areas of science, that guarantee the competitiveness of the national economy in the world market;

- lack of effective coordination of innovative work financed by individual executive bodies (the Ministry of Health, the Ministry of Agriculture, etc.), which prevents the consolidation of financial, human and organizational resources of the state for the implementation of significant scientific and production projects, as well as inventory and introduction into economic turnover of the results of scientific and technical activities, intellectual property obtained from budget funds in related industries the real sector of the economy;

- Despite the adoption of several regulatory legal acts by the government, there is still a weakness in the cooperative ties between scientific organizations, educational institutions, and industrial enterprises;

- unelaborate modern forms of innovative management, technology transfer, and monetization of innovations (through the market of scientific and technical products);

At the same time, the key economic elements limiting the innovative endeavor of organizations in the real sector of the economy indicate low innovative potential, scarcity of private finances to grow this type of activity, huge cost of innovations, financial risks and time-consuming repayment periods;

- insufficient informational transparency of the innovative domain, initially, absence of data on latest technologies and potential markets for a primarily novel product, as well as evidence offered to private investors and credit firms about investing objects with potentially favorable profits;

- A comparatively underdevelopment of small innovative entrepreneurship;

- Lack of innovative culture among population and entrepreneurs.

The development of a modern Uzbekistan is happening in settings of the emergent interdependence of world economies. Such tendencies in the context of a global change emphasize the issues of countries exercising competitive advantages.

Our research indicates that the most crucial competitive advantage in modern-day environments is the knowledge level and its concrete application in social and economic growth. These aspects define the status of the country in the world community, standard of living, and the national security. In countries of the Organization for Economic Cooperation and Development, 80-90 percent of GDP development is attributed to innovations. Studies show that the shift of these countries to the innovative path of progress has become feasible due to the creation of innovative national systems (NIS).

New emerging economies are determining their innovative system with the import of innovative technologies. The functional innovative model demonstrated that the rational practice of imported scientific and technological accomplishments deliver a significant increase in GDP but also contribute to reaching a higher rate of the economically developed countries of the world. A particular feature of the innovative policy of these countries is a selective approach to help and encourage certain businesses and distinct high-tech industries. Developed countries perceive a key to their effectiveness in the long term in enhancing the manufacturability of their economies in the field of information and telecommunication systems, "green economy", healthcare, artificial intelligence, energy, and transport. The United States, EU countries, and Japan consider that advanced technologies in these areas will help them to create a new, technological structure that ensures dynamic economic growth and global economic supremacy. Consequently, state policy is designed to stimulate above mentioned areas in these countries. 
The modern tendency in the establishment of a "knowledge economy" in nations with advanced economies is the decline of the "state order" for science achieved from the national budgets. The scientific divisions of large organizations, small and medium-sized high-tech enterprises are improving their positions in national scientific and technological expansion. Also, they depend on the educational system formed with the support of the goverment, infrastructure, and economic benefits.

To activate of the national intellectual potential, solve primacy tasks of social, economic, and scientific-technical growth, theoretical approaches of innovative development should be identified. Additionally, a new institutional environment favorable to the vibrant organization of these processes in the perspective of post-industrial development requests establishment. Innovative development should be concentrated on systematic and efficient efforts of the state, private business, and civil society institutions to guarantee the active progress of Uzbekistan in the field of science, innovation and the digital economy.

At the same time, the practice of chief innovative countries appropriate for Uzbekistan and effective methods of arranging an adequate, innovative economy, involving the commercialization of scientific developments are of huge significance.

Medium and long-term priorities involve resolving a systemic issue based on the principle of concentration of budget means on R\&D (research and development) funding in major areas and exploiting the mechanism of public-private partnership.

The first direction includes efforts of the state on the extended reproduction of fundamental knowledge, improving the quality level of "human capital" - one of the main competitive advantages of Uzbekistan. Also, government involvement is crucial in the implementation of applied research in few priority areas to ensure competitiveness, including share increase of the capitalized part of the obtained results, in creating an innovative infrastructure that will transform knowledge into a viable product.

The second direction proposes that part of the functional drawing-ups and formation of innovative infrastructure is directed by the state, and technological reconstruction is mainly by the business itself.

\section{Conclusion}

The key objective of innovative development in the long run is the establishment of an open innovative system that provides formation of a viable product and services grounded on the practice of foreign scientific potential and technologies with selective encouragement for local development targeted at fulfilling priority tasks of reconstruction of the country's economy.

Our research indicates that the core directions of innovative growth of Uzbekistan in the medium term can be listed as following:

- Further development of prospects for business expansion, promoting attractiveness of innovations and investment of key industries;

- Accomplishment promising innovative activity of businesses and organizations;

- Organization of fruitful research applying balanced fundamental and practical investigation, intellectual capitalization, knowledge transfer and technology;

- matching secondary and higher education to international standards, in particular, the implementation of the Progress in International Reading Literacy Study[1], Program for International Student Assessment[2], Third International Mathematics and Science Study[3] programs in the secondary education system, modular education systems in a higher education;

- creating right conditions for establishment of a progressive technical and technological structure and attractiveness of the innovative regional area. 
In conformity with continuing objectives and the central directions of innovative advance for a medium term, the following duties are included:

- Development of an adequate innovative economy of human potential, consisting of determined and knowledgeable people with high prerequisites for innovative products;

- Growing investment activity in the breakthrough areas of new technological structures;

- Quick upgrading of the economy of the republic, based on contemporary values of the digital economy;

- Formation of a competitive division of research, development and conditions for its extended reproduction;

- Heavily investing resources in the innovative sphere;

- Improvement of mechanisms to identify public priorities of the innovative development;

- Protection of property rights for drawing-ups and analysis of innovations;

- determining indicators of innovative activity and creation of its monitoring system;

- Comprehensive education of managers working in the field of innovations;

- Dynamic participation of young generation in science.

In summary, a systematic solution of the tasks set for the innovative development of the country, the formation of a modern national innovative system will considerably increase the competitive potential of the economy as a whole. It will also help to create and strengthen its comparative advantages in science, education, development of scientific and technical potential, and development of high technologies, consequently bringing new sources of the economic growth and welfare of the population.

\section{References:}

1. P. F. Drucker, The discipline of innovation. Harvard business review, (80) 95-104, (2002).

2. E. Mansfield, J. Y. Lee, (1996). The modern university: contributor to industrial innovation and recipient of industrial R\&D support. Research policy, 25(7) 1047-1058 (1996).

3. R. N. Nielsen, feeding food producers with (Regional) knowledge for innovation. Toward a theoretical underpinning of the feat 2015 project, (2008).

4. M. E. Porter, S. Stern, and Innovation: location matters. MIT Sloan management review, 42(4), 28, (2001).

5. B. Szántó, Innovation in crisis: Hungary before and after the watershed of 1989. Tec novation, 14(9) 601-611 (1994).

6. B. C. Twiss, Managing technological innovation. Longman Publishing Group, (1986).

7. F. M. Scherer, Innovation and growth: Schumpeterian perspectives. MIT Press Books, 1, (1986).

8. S. Winter, F. Malerba, R. Nelson, L. Orsenigo, 'History-friendly'models of industry evolution: the computer industry. Industrial and corporate change, 8(1), 3-40, (1999).

9. C. Freeman, National systems of innovation: the case of Japan. Technology policy and Economic Performance, London, Printer Publishers, (1987).

10. B. A. Lundvall, National Innovation Systems: Towards a Theory of Innovation and Interactive Learning (London Pinter 1992).

11. E. Jang, M. S. Park, K. Han, W. Choi, J. Joo, ASEM Eco-Innovation Index , (2016).

12. A. I. Anchishkin, Nauchno-tehnicheskij progress i intensifikacija proizvodstva, 94 (Politizdat 1981).

13. V. M. An'shin, i dr. Innovacionnyj menedzhment. Delo, (2003). 
14. V. N. Arhangel'skij. Upravlenie nauchno-tehnicheskim progressom $v$ mashinostroenii. (" Mashinostroenie",1983).

15. A. A. Dagaeva, V. M. An'shina. Koncepcii, strategii i mehanizmy innovacionnogo razvitija. ( Delo, 2006).

16. N. B. Ermasova, S. V. Ermasov. Finansovyj menedzhment. (Jurajt, 2010).

17. L. Je. Mindeli, \& V. A. Vasin. Nacional'naja innovacionnaja Sistema. 142 (CISN, 2002).

18. K. F. Puzynja, A. S. Zapasnjuk, Jekonomicheskaja jeffektivnost' nauchnoissledovatel'skih i opytno-konstruktorskih razrabotok v mashinostroenii, (1978).

19. N. Z. Solodilova, V. G. Versan, V. I. Sis'kov, , L. G. Dubickij, , S. H. Ekshembiev Integracija proizvodstva i upravlenija kachestvom produkcii. 320 (6), (1995).

20. A. I. Tatarkin, Modernizacionnoe obnovlenie rossijskogo prostranstva na osnove innovacionnyh iniciativ. (1) 6-33, (2016).

21. R. A. Fathutdinov, Innovacionnyj menedzhment. 400 (Piter, 2003)

22. S. S. Guljamov, A. M. Abdullaev, Innovacionnyj potencial i ego vlijanie na konkurentnoe razvitie jekonomiki strany. (2016).

23. M. A. Ikramov, E. S. Margianti, Systematical analysis of the position and further development of Uzbekistan national industry in the case of economic modernization.Monograph. Indonesia, Jakarta. Indonesia. Jakarta. (Gunadarma Publisher 2014).

24. A. M. Kadyrov, S. G. Sevlikjanc, Otto, O. Je., A. T. Ahmedieva, Informacionnoinnovacionnoe razvitie jekonomiki Uzbekistana. Monografija. (Iktisodijot, 2011).

25. M. A Mahkamova, Formirovanie organizacionno-jekonomicheskogo mehanizma upravlenija innovacionnoj dejatel'nost'ju na promyshlennyh predprijatijah Respubliki Uzbekistan, (Doctoraldissertation, TGTU, 2004).

26. M. P. Narzakulova, Puti formirovanija nacional'noj innovacionnoj sistemy. Jekonomika i finansy, 9 (Uzbekistan 2012)

27. A. F. Rasulev, D. V. Trostjanskij, Razvitie innovacionnoj dejatel'nosti nacional'noj jekonomiki v postkrizisnyj period. Jekonomika i finansy, 1 (Uzbekistan 2011)

28. D. V Trostjanskij, A. F. Rasulev, O. A. Islamova, Vestnik Nauka, obrazovanie, jekonomika. Serija: Jekonomika, 2 (12), (UGNTU , 2015).

29. I. Ansoff, Strategicheskij menedzhment, 344, (Piter, 2009).

30. M. H. Mescon, M. Albert, F. Khedouri, Osnovy menedzhmenta (Moscow, Delo Publ, 1997).

31. F. Jansen, Jepoha innovacij. ( INFRA, 2002).

32. L. S. Valinurova, N. A. Kuz'minyh, Ocenka urovnja innovacionnogo razvitija otraslej promyshlennosti, 6 (Innovacii,2007).

33. G. Gol'dshtejn, Ja. Strategicheskie aspekty upravlenija, 31 (NIOKR, 2000).

34. M. P. Golik, Analiz. " Finansy i statistika", (1987).

35. S. V.. Il'demenov, A. S. Il'demenov, V. P. Vorob'ev, Innovacionnyj menedzhment. (2002).

36. C. Freeman, National systems of innovation: the case of Japan. Technology policy and Economic Performance, London, Printer Publishers, (1987).

37. B. A. Lundvall, National Innovation Systems: Towards a Theory of Innovation and Interactive Learning (London: Pinter). Lundvall, B-A. and Borrás, S.(1997) The globalisation learning economy: implication for innovation policy, TSER programme, DG XII, Commission of the European Union. MacKenzie, S. and Podsakoff, P.(2012) Common method bias in marketing: Causes, mechanisms, and procedural remedies, Journal of Retailing, 88(4), 542-555, (1992).

38. O merah po dal'nejshemu ukrepleniju infrastruktury nauchno-issledovatel'skih uchrezhdenij i razvitiju innovacionnoj dejatel'nosti. Postanovlenie Prezidenta Respubliki 
Uzbekistan №PP-3365 01.11.2017 g.// Nacional'naja baza dannyh zakonodatel'stva, 01.11.2017 g., № 07/17/3365/0195

39. Ob obrazovanii ministerstva innovacionnogo razvitija Respubliki Uzbekistan. Ukaz Prezidenta Respubliki Uzbekistan za №UP-5264 29.11.2017 g. // Nacional'naja baza dannyh zakonodatel'stva, 01.12.2017 g., № 06/17/5264/0339. 